\title{
EVALUASI APLIKASI SEMI-IMMERSIVE VIRTUAL REALITY PADA BIDANG PENDIDIKAN MENURUT ASPEK HEURISTIK DAN PEMBELAJARAN
}

\author{
Erick Paulus $^{1)}$, Mira Suryani' ${ }^{2)}$, Riva Farabi ${ }^{3)}$, Intan Nurma Yulita ${ }^{4)}$, Aditya Pradana ${ }^{5)}$ \\ 1,2,3,4,5)Teknik Informatika, Departmen Ilmu Komputer \\ Universitas Padjadjaran \\ e-mail: erick.paulus@unpad.ac.id ${ }^{1)}$, mira.suryani@unpad.ac.id ${ }^{2)}$, \\ rivafarabi_babeheer@yahoo.com ${ }^{3)}$,intan.nurma@unpad.ac.id ${ }^{4)}$, aditya.pradana@unpad.ac.id ${ }^{5)}$
}

\begin{abstract}
ABSTRAK
Makalah ini memaparkan percobaan evaluasi komprehensif terhadap aplikasi virtual reality (VR) bertipe semi-immersive dari sisi heuristik disain antarmuka aplikasi, peningkatan kemampuan kognitif, dan peningkatan motivasi belajar ketika aplikasi digunakan dalam proses pembelajaran. Evaluasi terhadap disain antarmuka VR ini menggunakan metode heuristik yang diusulkan oleh Sutcliffe, yaitu sebanyak dua belas prinsip. Selain faktor usabilitas, evaluasi heuristik ini mampu memberikan panduan evaluasi dengan memperhitungkan faktor keberadaan pengguna ketika berada dalam lingkungan maya. Hasil proses inspeksi evaluasi heuristik ini adalah penggabungan nilai evaluasi dari tiga orang penilai. Hasil evaluasi menunjukan bahwa secara heuristik aplikasi BIOTALAUT VR sudah merepresentasikan kondisi lingkungan bawah laut dengan baik. Namun ada beberapa fitur disain yang perlu diperbaiki, yaitu interaksi antar objek, grafik objek $3 D$ biota dan fungsi kontrol. Sedangkan, proses evaluasi dari segi peningkatan kemampuan kognitif diimplementasikan pada 30 siswa tingkat sekolah menengah pertama melalui kegiatan pretes dan postes kemudian dianalisa secara statistik. Selain pretes dan postes, siswa juga mengisi kuisioner untuk mengetahui tingkat motivasi belajar setelah menggunakan aplikasi. Kemudian, setelah aplikasi digunakan pada proses pembelajaran, terdapat perbedaan kemampuan kognitif yang signifikan ke arah positif dengan nilai sig-value sebesar 0.448 dan peningkatan motivasi dilihat dari nilai rata-rata central tendency sebesar 4.49. Adapun hasil evaluasi ini dapat digunakan sebagai bahan pertimbangan dalam pengembangan aplikasi selanjutnya khususnya dari sudut pandang disain antarmuka aplikasi maupun dari konteks pembelajarannya. Selain itu, kejadian munculnya gejala cybersickness pada pengguna juga ditelaah dan dilaporkan dalam penelitian ini. Adapun posisi gerakan pengguna saat menjalankan aplikasi VR dan perangkat keras yang dipakai menjadi aspek utama yang menyebabkan cybersickness tersebut.
\end{abstract}

Kata Kunci: cybersickness, evaluasi usabilitas heuristik, , kemampuan kognitif, motivasi belajar, virtual reality

\begin{abstract}
This study describes about comprehensive evaluation towards semi-immersive virtual reality (VR) application in the education field from heuristic, the improvement of cognitive ability, and the learning motivation aspect. The heuristic evaluation adopted twelve heuristic rules that proposed by Sutcliffe. Aside from the usability factors, the proposed evaluation scheme is able to give the evaluation guide with concern about user presence in virtual environment. The evaluation process involves three assessors. The evaluation results shown that the BIOTALAUT VR application has been representing the underwater condition very well based on heuristics. Nevertheless, there are some feature designs that should be repaired such as interaction between objects, the graphic of $3 D$ biota objects and control function. Whereas, the evaluation of cognitive ability conducted by implemented the application in the learning process. There are 30 students used the application, then evaluated by pretest and postest for measuring the cognitive ability, and questionnaire for measuring the learning motivation. After learning process using the application, there are significant differences in cognitive ability. It can be seen from sig-value of 0.448 and the improvement of learning motivation that can be seen from the average of central tendency with value 4.49 . The evaluation results from this study can be used as recommendation in the future development process, especially from user interface and learning process aspect. During the evaluation process, the researcher found that the symptoms of cybersickness appear in every VR user. But, the duration of usage to cause cybersickness can be different for every user. It's depends on the hardware specification and the position of user while running $a$ VR application.
\end{abstract}

Keywords: cognitive ability, cybersickness, heuristic usability evaluation, learning motivation, virtual reality

\section{Pendahuluan}

$\mathrm{T}$ eknologi dan media memiliki peran penting dalam proses pembelajaran. Temuan dari berbagai penelitian tentang difusi teknologi dan pemanfaatan Information and Communications Technology (ICT) dalam pendidikan menunjukkan adanya kecenderungan siswa untuk mengintegrasikan teknologi ke dalam proses pembelajarannya [1]. Penggunaan teknologi Virtual Reality (VR) dalam dunia pendidikan dan pelatihan merupakan salah satu contoh pemanfaatan ICT dan merupakan evolusi dari Computer-Assisted Instruction (CAI) atau Computer-based Training (CBT) yang menawarkan interaksi yang lebih alami, atraktif dan immersive [2]. Beberapa contoh pemanfaatan teknologi VR di bidang pendidikan teknik [3], [4] menunjukan bahwa VR merupakan media pembelajaran kreatif masa depan. Selain itu, teknologi perangkat VR dan ponsel pintar dimana aplikasi VR dapat dijalankan cukup bervariasi dan cukup terjangkau di pasaran sehingga memungkinkan 
pemanfaatannya digunakan secara pribadi oleh siswa. Hal ini juga memberikan keleluasaan bagi siswa untuk lebih fokus mempelajari dan mengulang materi pembelajaran.

Penggunaan VR untuk pembelajaran yang mulai massif ini perlu ditunjang dengan evaluasi sebagai langkah untuk menjaga kesinambungan aplikasi VR tersebut. Evaluasi VR yang dapat dilakukan adalah dari sisi usabilitas aplikasi dan implementasinya pada proses pembelajaran. Evaluasi heuristik umumnya menekankan pada usabilitas dari desain aplikasi. Barnum [5] mengatakan usabilitas sistem yang rendah akan menghambat efisiensi dan efektifitas penggunaan. Oleh karena itu, metode evaluasi diperlukan untuk mengukur usabilitas dari disain aplikasi dan mengidentifikasi area permasalahan yang mungkin terjadi ketika aplikasi digunakan.

Evaluasi heuristik merupakan metode inspeksi yang umum digunakan oleh para penguji untuk mengukur usabilitas antarmuka aplikasi. Dix [6] dalam buku Human Computer Interaction (HCI) mencatat bahwa terdapat banyak metode evaluasi heuristic, diantaranya adalah metode evaluasi Nielsen's ten heuristics, Shneiderman's eight golden rules dan Norman's seven principles. Namun ketiga metode evaluasi tersebut belum mengeksplorasi secara ditail aspek kealamian ketika pengguna berada dalam lingkungan maya. Lalu, Sutcliffe [7] mengusulkan dua belas prinsip heuristik untuk mengevaluasi tampilan antarmuka lingkungan maya. Metode evaluasi ini didasarkan pada Nielsen's ten heuristics, dan dikembangkan khusus untuk aplikasi VR dengan memperhatikan aspek usabilitas dan keberadaan.

Penulis memaparkan percobaan evaluasi usabilitas heuristik terhadap aplikasi VR bertipe semi-immersive dengan mengadopsi dua belas prinsip heuristik Sutcliffe. Selain dari evaluasi heuristik aplikasi, evaluasi penggunaan VR pada proses pembelajaran perlu diupayakan. Hal ini dikarenakan pengguna terutama siswa sebagai salah satu stakeholder aplikasi harus merasakan manfaat pembelajaran. Diharapkan pemanfaatan VR sebagai sarana belajar kreatif ini mampu mendongkrak motivasi dan lebih jauh lagi adanya peningkatan prestasi belajar siswa. Oleh karena itu, pada studi ini juga dipaparkan proses ujicoba penggunaan teknologi VR sebagai media pembelajaran bagi siswa. Aplikasi BiotaLaut VR yang digunakan memperkenalkan kehidupan biota laut yang terancam punah. Aplikasi ini dikembangkan berdasarkan tema pembelajaran mengenai konservasi pada mata pelajaran IPA di tingkat SMP. Aplikasi ini diujicobakan kepada siswa tingkat SMP. Kemudian, pemanfaatan teknologi VR ini dievaluasi dengan kuisioner untuk mengetahui peningkatan motivasi [8] dan pemberian pretespostes untuk mengetahui ada atau tidaknya peningkatan kemampuan kognitif siswa [9]. Selanjutnya, penulis juga memaparkan kemungkinan terjadinya cybersickness [10], [11] dari penggunaan alat kacamata Google Cardboard versi 1 dan ANTVR kit selama proses ujicoba.

\section{A. Virtual Reality}

Mengacu pada Bamodu dan Ye [12], Virtual Reality (VR) merupakan sebuah media interaksi antara manusia dan komputer berupa simulasi interaktif yang dapat memunculkan efek perasaan keberadaan dalam lingkungan virtual melalui berbagai macam umpan balik seperti sensor kanal virtual, aura, sentuhan, bau-bauan, dan sebagainya. Pengembangan VR ini melibatkan multidisiplin ilmu dalam ilmu komputer seperti komputer grafis, pengolahan citra, pengenalan pola dan kecerdasan buatan, jaringan, dan multimedia. VR memiliki tiga fitur utama yang disebut 3I, yaitu: Immersion, Interaction, dan Imagination. Immersion merupakan aspek perasaan kehadiran diri sendiri di dalam lingkungan digital yang dibangun. Interaction merupakan cara pengguna berkomunikasi dengan sistem VR yang berada di lingkungan 3 dimensi yaitu contohnya dengan menggunakanSspace Ball dan Head-Mounted Device (HMD). Imagination adalah kemampuan dari pengembang VR untuk mencapai tujuan tertentu ketika mengembangkan sebuah aplikasi VR.

Berdasarkan aspek perasaan kehadiran dalam lingkungan virtual, aplikasi VR dibagi ke dalam 3 jenis yaitu nonimmersive, immersive, dan semi-immersive. Non-immersive adalah kategori aplikasi VR yang paling sedikit memunculkan perasaan keberadaan pengguna ketika menggunakan aplikasi. Biasanya aplikasi yang dibangun merupakan aplikasi lingkungan Desktop 3D. Contoh dari aplikasi VR yang termasuk kategori non-immersive adalah sistem CAD. Immersive adalah kategori VR paling mahal dimana terdapat animasi 3D yang dibangun oleh komputer. Hal ini memunculkan perasaan keberadaan pada lingkungan virtual paling tinggi. Selain itu, interaksi yang kuat antara manusia dan sistem juga menggunakan Head Mounted Display (HMD). Contoh dari aplikasi VR kategori immersive ini banyak digunakan pada bidang kesehatan seperti uji keseimbangan bagi manula dan disabilitas [13] dan aplikasi VR berkenaan dengan simulasi penanganan pasien oleh dokter [14]. Namun, penggunaan dari aplikasi pada kategori ini memerlukan perhatian khusus seperti lama penggunaan dan teknis penggunaan yang tepat, karena memungkinkan munculnya cybersickness pada penggunanya [15]. Secara rinci ulasan mengenai cybersickness dibahas pada bagian D di paper ini. Adapun semi-immersive VR merupakan kategori VR yang menyediakan perasaan keberadaan yang tinggi namun tetap dengan penggunaan lingkungan desktop yang sederhana. Contoh aplikasi VR pada kategori semi-immersive ini antara lain simulasi mengemudi dan aplikasi BIOTALAUT VR yang diujicobakan dalam penelitian ini.

\section{B. Google Carboard dan ANTVR kit}

Beberapa perangkat VR semi immersive semakin banyak dipasaran seperti Google Cardboard danANTVR. 
Selain murah, Google Cardboard memiliki konsep unik dimana perangkat dirakit sendiri dari pola potongan kardus yang dilipat dan dibentuk seperti kacamata. Sedangkan, ANTVR terbuat dari plastik dan busa sehingga pengguna merasa lebih nyaman dalam penggunaanya. Adapun Cara kerja kedua perangkat ini hampir sama, yaitu dengan menyisipkan telepon pintar yang menjalankan aplikasi VR di depan kacamata dengan layar telpon pintar menghadap kedua lensa. Gambar yang ditampilkan oleh monitor telpon pintar akan diteruskan ke mata pengguna melalui lensa bikonveks pada kacamata tersebut sehingga pengguna seolah-olah melihat langsung suasana lingkungan yang ditampilkan monitor telpon pintar. Google Cardboard versi pertama menggunakan dua magnet yang dipasang di luar dan dalam sebelah kiri headset sebagai alat input dari sensor magnetometer pada telpon pintar. Namun, ANTVR kit tidak dilengkapi dengan alat input magnet melainkan tombol mekanik.

\section{Evaluasi Heuristik}

Evaluasi heuristik merupakan salah satu metode inspeksi usabilitas yang bertujuan untuk mencari kelemahan dari desain antarmuka yang ada pada suatu perangkat lunak. Evaluasi heuristik melibatkan sekelompok kecil penilai untuk menguji disain antarmuka berdasarkan prinsip-prinsip heuristik yang sudah ditetapkan [16]. Sutcliffe dan Gault [7] melakukan modifikasi dan penyesuaian terhadap prinsip-prinsip heuristik Nielsen dengan menfokuskan pada aspek usabilitas dan kehadiran pengguna pada lingkungan maya. Proses penyesuaian tersebut menghasilkan 12 prinsip heuristik yang dapat digunakan untuk mengevaluasi usabilitas aplikasi VR.

Selanjutnya, setiap prinsip heuristik dinilai peringkat permasalahannya untuk mengetahui prioritas pengembangan sistem selanjutnya. Ada tiga faktor yang mempengaruhi peringkat permasalahan usabilitas, yaitu seberapa sering masalah tersebut terjadi (frekuensi), seberapa sukar masalah tersebut dapat diatasi (dampak masalah), seberapa tahannya pengguna menghadapi masalah tersebut (persistensi masalah). Adapun skala penilaian [2] untuk mengukur peringkat permasalahan usabilitas bernilai antara 0 dan 4, masing-masing adalah tidak ada masalah, kosmetik, minor, major, dan bencana.

\section{Cybersickness}

Kejadian cybersickness atau virtual reality sickness merupakan gejala yang mungkin terjadi saat menggunakan aplikasi VR. Cybersickness yang umumnya menyebabkan mata lelah, pusing, atau mual ini bisa diakibatkan oleh beberapa faktor, seperti jenis kelamin, usia, penyakit yang dialami, serta posisi pengguna saat menggunakan perangkat VR. Gangguan teknis dari perangkat VR juga menjadi salah satu faktor yang membuat seseorang mengalami cybersickness. Gangguan tersebut bisa berupa ketidaksinkronan antara alat tracking dengan posisi anggota tubuh pengguna, seperti alat head tracking. Gangguan juga bisa disebabkan oleh lag pada tampilan. Lag terjadi karena adanya jeda yang cukup lama pada tampilan yang membuat gerakan pada video menjadi patah. Flicker atau efek kedipan yang disebabkan oleh perubahan kecerahan cahaya monitor dapat menjadi faktor teknis penyebab cybersickness. Efek flicker dapat dicegah dengan menaikkan tingkat refresh rate monitor, dimana $30 \mathrm{~Hz}$ merupakan tingkat fresh rate yang cukup baik untuk menghilangkan flicker [11].

\section{E. Motivasi Belajar}

Motivasi merupakan kegiatan mendorong seseorang agar motif-motif yang ada dalam dirinya terpacu untuk melakukan sesuatu sehingga tujuan yang diinginkan tercapai [17]. Menurut Santoso, dalam pembelajaran motivasi terdiri dari 3 jenis, yaitu gabungan motivasi dan emosi mempengaruhi pembelajaran, motivasi intrinsik dalam belajar, dan efek motivasi pada usaha yang digunakan untuk belajar [9]. Sebagai pendidik, tugas yang perlu dilakukan terhadap siswanya adalah memotivasi siswa agar mau belajar. Motivasi yang baik berasal dari pribadi siswa (motivasi intrinsik) dimana kesadaran belajar muncul dari diri siswa sendiri. Namun tidak menutup kemungkinan motivasi siswa perlu dibangkitkan secara eksternal (motivasi eksternal) melalui umpan-umpan kreatif yang diberikan oleh pendidik sehingga siswa tertarik. Salah satu umpan kreatif untuk memotivasi siswa secara eksternal adalah dengan memberikan materi ajar dan cara ajar yang kreatif.

\section{F. Kemampuan Kognitif sebagai Salah Satu Faktor Pengukuran Prestasi Belajar}

Kemampuan kognitif merupakan kemampuan kerja otak dalam mengamati objek-objek tertentu sehingga timbul permrosesan informasi menjadi pengetahuan yang dialami berdasarkan pengalaman sendiri [18]. Berdasarkan taksonomi Bloom, ranah kemampuan kognitif ini dibagi ke dalam enam aspek, yaitu: pengetahuan (recall), pemahaman (comprehension), penerapan (application), analisis (analysis), sintesa (synthesis), dan evaluasi (evaluation) [13]. Implementasi dalam kegiatan pembelajaran kemampuan kognitif ini dapat diketahui dengan melakukan tes terhadap siswa berdasarkan materi yang diberikan. Representasi kemampuan kognitif biasanya disajikan dalam bentuk numerik berkorelasi terhadap tujuan pembelajaran yang ingin dicapai. 


\section{Metode}

\section{A. Lokasi dan Subjek Penelitian}

Lokasi yang menjadi tempat penelitian yaitu Madrasah Tsanawiyah Ma'Arif, Kabupaten Sumedang sebanyak 15 orang dan Sekolah Menengah Pertama Muhammadiyah 1 Jatinangor, Kabupaten Sumedang sebanyak 15 orang sehingga total jumlah subjek penelitian adalah sebanyak 30 orang Subjek penelitian yang digunakan dalam penelitian ini adalah siswa dari kelas VII hingga IX. Subjek ini dipilih berdasarkan pertimbangan pengetahuan TIK, aktivitas akademis yang mempelajari tentang konservasi, penggunaan kurikulum yang sama, dan kebijakan pihak sekolah. Dalam penelitian ini, pengambilan sampel dilakukan dengan menggunakan metode Simple Random Sampling dimana pengambilan sampel dilakukan secara acak tanpa memperhatikan strata yang berada dalam populasi seperti prestasi, tingkat ekonomi, jurusan, dan sebagainya.

\section{B. Metode Evaluasi Heuristik}

Langkah pertama adalah melakukan audit teknologi berkaitan dengan cara pengoperasian, keterbatasan umpan balik, jenis interaksi dan grafik yang realistik. Setelah audit teknologi selesai dilakukan, penilai melakukan serangkaian tugas pengguna dan mencatat semua kesulitan atau masalah yang dihadapi. Masalah-masalah ini kemudian dipetakan dengan pendekatan heuristik dan diberikan peringkat permasalahan untuk setiap prinsip heuristiknya. Langkah terakhir adalah mendiagnosa fitur desain yang bertanggung jawab atas masalah yang dihadapi dan memberikan peringkat keparahan. Adapun daftar parameter masalah nilai peringkat keparahan untuk pengelompokan fitur desain dipaparkan pada referensi [7].

\section{Metode Evaluasi Pembelajaran}

Instrumen penelitian yang digunakan pada penelitian ini terbagi menjadi dua yaitu soal pretes-postes dan kuisioner motivasi. Soal pretes-postes terdiri dari enam soal pilihan ganda dimana tiga diantaranya merupakan soal yang menguji kemampuan pemahaman kognitif dari data visual yang disajikan pada aplikasi. Sedangkan tiga pertanyaan berikutnya merupakan soal yang menguji kemampuan kognitif dari informasi audio.

Hasil dari pretes dan postes ini dievaluasi menggunakan metode statistik one-way ANOVA yang bertujuan untuk mengetahui signifikasi perbedaan kemampuan kognitif siswa sebelum dan sesudah menggunakan aplikasi VR. Untuk melakukan uji one-way ANOVA, terlebih dahulu dilakukan uji normalitas dan homogenitas dari data. Uji normalitas yang digunakan dalam penelitian ini adalah uji Kolmogorov-Smirnov dengan rumus (1) sebagai berikut:

$$
z_{i}=\frac{x_{i}-\bar{x}}{s}
$$

dimana $L=\operatorname{Maks}\left|F\left(z_{i}\right)-s\left(z_{i}\right)\right|$, dengan

$F\left(z_{i}\right)=\mathrm{P}\left(\mathrm{Z}<z_{i}\right) ; Z \in N(0,1)$

$s\left(z_{i}\right)=$ proporsi cacah $Z \leq z_{i}$ terhadap seluruh $Z$

daerah kritis uji normalitas : $D K=\{L \mid L<L \alpha ; n\}$, n adalah ukuran sampel.

Apabila hasil analisis menunjukan bahwa nilai signifikansi (sig.) uji ini bernilai di atas 0,05 ( $p>0,05$ ), maka disimpulkan bahwa data berasal dari populasi yang terdistribusi secara normal. Sebaliknya, apabila hasil analisis menunjukan bahwa nilai signifikansi (sig.) uji ini bernilai di bawah $0,05(\mathrm{p}<0,05)$, maka disimpulkan bahwa data berasal dari populasi yang terdistribusi secara tidak normal. Selajutnya setelah dilakukan uji normalitas terhadap nilai pretes dan postes, kita perlu melakukan uji homogenitas data untuk mengetahui data berasal dari populasi yang sama (homogen) atau tidak (tidak homogent). Uji homogenitas yang digunakan adalah Uji Lavene (2) sebagai berikut:

$$
W=\frac{(n-k) \sum_{i=1}^{k} n_{i}\left(\overline{x_{l}}-\overline{x_{\ldots}}\right)^{2}}{(k-1) \sum_{i=1}^{k} \sum_{j=1}^{n}\left(\overline{x_{l \jmath}}-\bar{x}_{l}\right)^{2}}
$$

Dimana $n=$ jumlah data observasi, $k=$ banyaknya kelompok, $x_{i j}=\left|y_{i j}-\bar{y}_{i}\right|, \bar{y}_{i}=$ rata-rata dari kelompok ke- $i, \bar{x}_{l}=$ rata-rata kelompok dari $x_{i}, \bar{x}_{\ldots}=$ rata-rata menyeluruh dari $x_{i j}$. Setelah diperoleh nilai $\mathrm{W}$ dari hasil perhitungan, maka selanjutnya dilakukan penarikan kesimpulan dengan membandingkan nilai $\mathrm{W}$ dengan $F_{\alpha ; k-1 ; n-k)}$.

Adapun soal kuisioner untuk mengetahui motivasi siswa terdiri dari lima pernyataan persetujuan yang meliputi: keunikan VR, tingkat kesenangan menggunakan VR, peningkatan semangat belajar, kemudahan penggambaran visual dan audio, dan pemberian pengalaman baru. Tingkat persetujuan pernyataan dimulai dari tidak sesuai, sangat tidak setuju hingga sangat setuju. Kuisioner mengenai motivasi ini mengadopsi dari Zaharias [8]. Skala pengukuran yang digunakan dalam form penilaian dan kuisioner adalah skala Likert (Likert Scale). Tidak setuju diberikan nilai 0 , sangat tidak setuju 1, hingga sangat setuju 5. Hasil konversi data kuisioner ke dalam skala Likert ini selanjutnya digunakan untuk menghitung nilai central tendency. Central tendency merupakan nilai yang merepresentasikan nilai rata-rata persetujuan semua siswa untuk setiap poin pernyataan. Poin pernyataan dengan nilai central 
tendency-nya $\geq 3.50$ menandakan keseluruhan siswa menyetujui pernyataan tersebut dan sebaliknya apabila nilai central tendency-nya $<3.50$ maka pernyataan tersebut tidak setujui oleh keseluruhan siswa [19].

\section{HASIL}

Proses evaluasi terhadap aplikasi VR semi-immersive dibagi menjadi 2 tahap utama, yaitu proses evaluasi heuristik terhadap disain antarmuka aplikasi dan evaluasi pembelajaran. Evaluasi dilakukan terhadap aplikasi BIOTALAUT VR. Aplikasi ini merupakan pilot project untuk pengembangan media pembelajaran kreatif yang bertujuan mengajarkan siswa tentang karakteristik, prilaku, konservasi beberapa biota laut berbasis VR. Evaluasi heuristik melibatkan 3 orang penilai yang mendalami bidang Interaksi Manusia dan Komputer khususnya metode evaluasi. Sebelumnya, penilai belum pernah menggunakan aplikasi BIOTALAUT VR tetapi sudah biasa menggunakan aplikasi VR.

TABEL I

INTEPRETASI EVALUASI HEURISTIK DAN PERINGKAT PERMASALAHAN YANG DITEMUI

\begin{tabular}{|c|c|c|c|}
\hline No & Heuristik & Peringkat & Masalah yang ditemukan \\
\hline 1 & Natural engagement & 4 & $\begin{array}{l}\text { - Arah gelembung tidak ke arah permukaan laut, jika kepala menunduk } \\
\text { - Ada satu hiu yang bergerak sangat lambat, sehingga terlihat tidak alami } \\
\text { - Ada satu hiu putih bertabrakan dan menembus hiu lain. } \\
\text { - Ada animasi gerakan tubuh Paus Orca yang tidak sesuai dengan arah gerakan. }\end{array}$ \\
\hline 2 & $\begin{array}{l}\text { Compatibility with the user's } \\
\text { task and domain }\end{array}$ & 3 & $\begin{array}{l}\text { - Aplikasi tidak kembali ke halaman menu Biota, ketika pengguna berada di lingkungan maya dan } \\
\text { menekan tombol exit dengan menggunakan fitur magnometer (interaksi geser magnet pada } \\
\text { Google Cardboard } \mathrm{v} 1 \text { ). } \\
\text { - Suara bawah laut pecah } \\
\text { - Ada sirip hiu yang menembus kandang } \\
\text { - Pointer menembus objek lain }\end{array}$ \\
\hline 3 & Natural expression of action & 2 & - Tombol info saat disorot tidak berubah warna \\
\hline 4 & $\begin{array}{l}\text { Close coordination of action } \\
\text { and representation }\end{array}$ & 1 & - Teks informasi yang ditampilkan terlihat jaggy (tidak halus) \\
\hline 5 & Realistic feedback & 1 & - Pengguna tidak langsung tahu fungsi tombol info sampai mereka melihat teks disamping biota. \\
\hline 6 & Faithful viewpoints & 1 & $\begin{array}{l}\text { - Secara umum baik, Adanya sedikit lag pada tampilan saat menggerakkan posisi kepala terlalu } \\
\text { cepat }\end{array}$ \\
\hline 7 & $\begin{array}{l}\text { Navigation and orientation } \\
\text { support }\end{array}$ & 0 & $\begin{array}{l}\text { - Terkadang terjadi disorientasi kamera terhadap tampilan yang disebabkan oleh sensor gyroscope } \\
\text { pada telpon pintar tertentu }\end{array}$ \\
\hline 8 & Clear entry and exit points & 2 & $\begin{array}{l}\text { - Aplikasi tidak kembali ke halaman menu Biota, ketika pengguna berada di lingkungan maya dan } \\
\text { menekan tombol exit dengan menggunakan fitur magnometer (interaksi geser magnet pada } \\
\text { Google Cardboard v1). }\end{array}$ \\
\hline 9 & Consistent & 2 & $\begin{array}{l}\text { - Gambar pointer menyerupai gelembung udara } \\
\text { - Ukuran teks informasi tidak konsisten } \\
\text { - Tombol info saat disorot tidak berubah warna menjadi kuning, seperti tombol play }\end{array}$ \\
\hline 10 & Support for learning & 1 & - Panduan penggunaan tersedia diawal namun kurang menarik untuk dibaca \\
\hline 11 & Clear turn-taking & N/A & - Pengguna tunggal, jadi tidak ada komunikasi antar avatar \\
\hline 12 & Sense of presence & 1 & - Adanya sedikit penundaan rendering \\
\hline
\end{tabular}

A. Audit Teknologi

Langkah pertama, penilai melakukan adaptasi terhadap aplikasi VR dan menghasilkan audit teknologi sebagai berikut

1) Operation of the user's presence: Bentuk kehadiran pengguna divisualisasi oleh pointer yang digunakn sebagai petunjuk fokus atau arah penglihatan ketika kepala pengguna bergerak. Pemilihan menu juga memanfaatkan Pointer tersebut.

2) Haptic feedback: karena tidak ada interaksi sentuhan saat menggunakan VR semi-immersive, maka interaksi umpan balik sentuhan diganti dengan perubahan warna pada setiap tombol yang dpilih. Perubahan warna tersebut terjadi jika pointer diarahkan kepada tombol.

3) Interactive techniques: Pengguna dapat melihat objek 3D dan informasi teks yang muncul di layar serta mendengarkan audio materi pembelajaran. Interaksi terhadap menu yang dipilih adalah melalui geser magnet (Google Cardboard) atau tekan tombol mekanik (ANTVR)

4) Realistic graphics: Aplikasi ini memiliki representasi visual yang tidak terlalu kompleks, sehingga pengguna dapat menjalankan tugas dengan mudah dan tepat.

\section{B. Hasil Evaluasi}

Langkah kedua, setiap penilai mengidentifikasi seluruh masalah yang ditemui dan memetakannya ke dalam 12 prinsip heuristik. Setelah temuan masalah digabungkan, ketiga penilai berdiskusi bersama untuk menentukan peringkat permasalahan dari masing-masing setiap prinsip heuristik. Identifikasi evaluasi heuristik dan peringkat masalahnya dapat dilihat pada Tabel I. Adapun klasifikasi masalah dan tingkat keparahan dari segi disain dapat dilihat pada Tabel II. 
TABEL II

KLASIFIKASI MASALAH DENGAN PERINGKAT KEPARAHAN DAN USULAN PENGEMBANGAN DISAIN BERDASARKAN FITUR DISAIN

\begin{tabular}{|c|c|c|c|}
\hline Fitur & Deskripsi Masalah & $\begin{array}{l}\text { Peringkat } \\
\text { Keparahan }\end{array}$ & Usulan Pengembagan Disain \\
\hline Grafik & Animasi Objek 3D & Gangguan sedang & Memperbaiki disain objek 3D khususnya detail gerakan tubuh biota \\
\hline Presence & $\begin{array}{l}\text { Pointer, masalah } \\
\text { manipulasi objek }\end{array}$ & Gangguan kecil & $\begin{array}{l}\text { Perbaiki simbol pointer dan perubahan warna ketika objek "info" } \\
\text { dipilih }\end{array}$ \\
\hline Interaksi & $\begin{array}{l}\text { Ada objek yang } \\
\text { menembus objek lainnya }\end{array}$ & Parah & $\begin{array}{l}\text { Perbaiki jalur pergerakan objek(biota) atau perlu ditambahkan efek } \\
\text { benturan (Collision) dan suara. }\end{array}$ \\
\hline Lingkungan & $\begin{array}{l}\text { Gelembung udang, suara } \\
\text { air kurang jelas }\end{array}$ & Gangguan kecil & $\begin{array}{l}\text { Perbaiki arah gelembung udara. } \\
\text { Perbaiki kualitas dan pengaturan suara. }\end{array}$ \\
\hline Kontrol & $\begin{array}{l}\text { Menu yang kurang } \\
\text { dipahami dan } \\
\text { memanipulasi objek }\end{array}$ & Gangguan kecil & $\begin{array}{l}\text { Menggunakan simbul menu yang lebih umum atau tambahkan tooltip. } \\
\text { Perbaiki program untuk mengatasi alat input dari sensor magnetometer. }\end{array}$ \\
\hline $\begin{array}{l}\text { Perangkat } \\
\text { keras }\end{array}$ & Disorientasi kamera & Gangguan kecil & $\begin{array}{l}\text { Pilih perangkat kacamata tracking dan sensor telpon pintar yang lebih } \\
\text { baik. }\end{array}$ \\
\hline
\end{tabular}

\section{PEMBAHASAN}

Aplikasi BIOTALAUT VR sudah merepresentasikan lingkungan bawah laut dan kelengkapan objek 3D yang diperlukan dengan baik, diantaranya adalah gelombang air, gelembung udara, efek pencahayaan, kandang, dan 3 objek biota. Namun beberapa interaksi antar objek yang ditampilkan masih kurang alami, lihat Tabel 1 dan 2 . Contohnya adalah jika kepala menunduk ke bawah, arah gelembung udara tidak menuju ke permukaan air. Kemudian ada beberapa objek yang menembus objek lainnya. Contohnya, gambar 1 menampilkan sirip kiri ikan hiu menembus kandang. Sebaiknya jika kedua objek bertabrakan, sistem perlu ditambah efek benturan (collision) dan ditambah efek suara. Selanjutnya, konsistensi terhadap jenis kontrol yang serupa seperti kontrol menu Play dan menu Info sebaiknya memiliki perubahan warna yang serupa ketika pointer diarahkan ke tombol yang dipilih. Hasil evaluasi juga menunjukan bahwa aplikasi tidak kembali ke halaman menu Biota, ketika pengguna menekan tombol exit dengan menggunakan fitur magnometer (interaksi geser magnet pada Google Cardboard v1). Tetapi jika pengguna menekan tombol exit melalui layar telepon pintar, aplikasi akan kembali ke halaman menu Biota. Oleh karena itu, perbaikan program diperlukan untuk mengatasi masalah ini sehingga aplikasi memiliki usabilitas yang lebih baik.

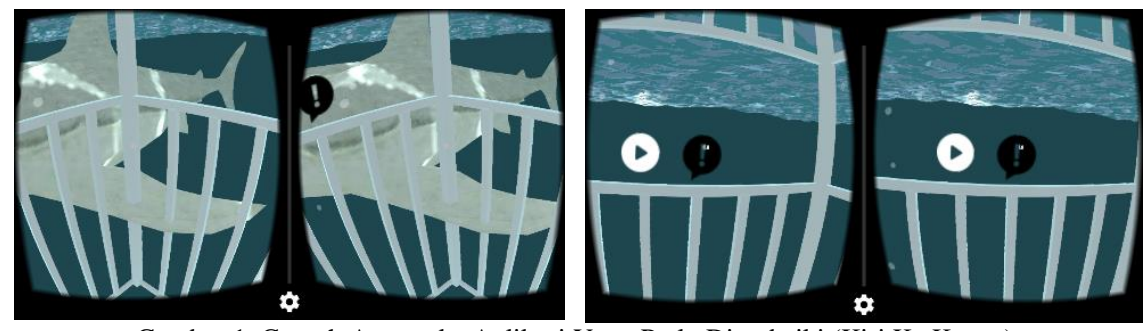

Gambar 1. Contoh Antamuka Aplikasi Yang Perlu Diperbaiki (Kiri Ke Kanan):

Sirip Hiu Menembus Kandang Dan Kontrol Warna Tombol

Selama proses evaluasi berlangsung, gejala cybersickness terjadi di setiap penilai dan siswa. Namun kapan seseorang mulai merasakan gejala tersebut sangat bervariasi. Menurut LaViola [11], Gejala ini dapat disebabkan oleh beberapa faktor, seperti jenis kelamin, usia, penyakit yang dialami, serta posisi pengguna saat menggunakan perangkat VR. Peneliti melalukan ujicoba terhadap beberapa posisi yang menyebabkan gejala cybersickness ini lebih mudah terjadi dengan kondisi usia relatif sama dan tidak ada kelainan penglihatan. Berdasarkan 10 pengguna yang diamati, posisi kepala ke atas dalam waktu yang relatih lama dan memutarkan kepala dengan cepat adalah pemicu utama gejala cybersickness tersebut. Penggunaan alat kacamata tracking juga memiliki peran dalam cybersickness. Selain itu, faktor perangkat kacamata dan telpon pintar seperti jenis lensa, ukuran lensa, kenyaman kacamata dan ukuran resolusi layar turut memberikan efek cybersickness. Penggunaan perangkat ANTVR menunjukan bahwa waktu pertama kali terjadinya gejala cybersickness memerlukan waktu yang lebih panjang dari pada perangkat Google Cardboard.

Pada pelaksanaan evaluasi pembelajaran (lihat Gambar 2), setiap siswa diberikan panduan penggunaan aplikasi BIOTALAUT VR dan headset VR. Kegiatan uji coba penggunaan aplikasi VR yang diimplementasikan kepada 30 siswa ini, memiliki waktu yang bervariasi antara 5-10 menit per siswa. Perhitungan waktu setiap siswa dihitung dari mulai membaca panduan hingga mencoba ketiga jenis hewan yang disajikan pada aplikasi VR. Perbedaan waktu ini kemungkinan dikarenakan oleh dua faktor yaitu: pembiasaan dalam menggunakan teknologi seperti smartphone dan kemampuan memahami pentunjuk pemakaian aplikasi dan headset VR. Waktu tersebut diluar kegiatan mengisi pretes, postes, dan form kuisioner. 


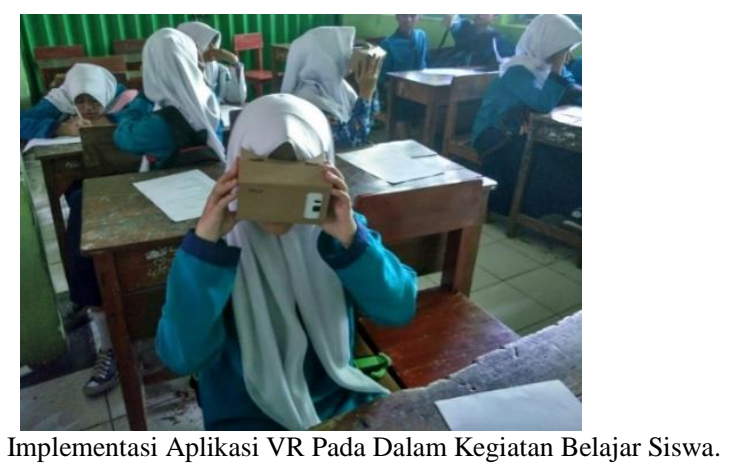

Data hasil pretes dan postes kemudian diolah dengan metode statistika one-way ANOVA untuk mengetahui perbedaan kemampuan kognitif antara sebelum dan sesudah menggunakan aplikasi VR seperti yang diuraikan pada bagian III. Dari hasil uji normalitas dengan Kolmogorov-Smirnov terhadap data pretes dan postes diperoleh nilai sig. sebesar 0.001. Jika dibandingkan $0.001<0.05$, maka data penelitian yang diperoleh tidak berdistribusi normal. Hasil uji normalitas data dapat dilihat pada Tabel III.

TABEL III.

HASIL UJICOBA NORMALITAS DATA DENGAN KOLMOGOROV-SMIRNOV BERDASARKAN SPSS

\begin{tabular}{llr}
\hline \hline $\mathrm{N}$ & & Unstandardized predicted Value \\
\hline Normal Parameter & Mean & 30 \\
& Std. Deviation & 4.43 \\
Most Extreme Diff & Absolute & 0.12 \\
& Positive & 0.22 \\
& Negative & 0.22 \\
Test Statistic & & -0.213 \\
& & 0.22 \\
\hline \hline
\end{tabular}

Kemudian dilakukan uji homogenitas data terhadap nilai prestes dan postes dengan menggunakan metode uji Lavene. Hasil yang diperoleh dari uji Lavene ini menyatakan bahwa nilai sig. yang diperoleh adalah $\mathrm{W}=0.430$. Jika dibandingkan, nilai $0.430>0.05$ maka data penelitian yang diperoleh tidak homogen. Dikarenakan data yang diperoleh tidak berdistribusi normal dan tidak homogen, maka peneliti mencoba melakukan transformasi data. Namun, setelah dilakukan transformasi data, data menjadi normal namun tidak homogen. Oleh karena itu, pengujian statistik yang diimplementasikan pada data penelitian adalah dengan menggunakan one-way ANOVA dengan koreksi menggunakan uji Brown Forysthe sehingga diperoleh nilai signifikansi P-value sebesar 0.448. Jika dibandingkan, nilai signifikasi P-value $<0.05$, sehingga memberikan kesimpulan terjadi perbedaan yang signifikan antara nilai pretes dan postes. Hal ini mengindikasikan terjadinya peningkatan kemampuan kognitif siswa dari sebelum menggunakan aplikasi VR dan sesudah menggunakan aplikasi VR dalam kegiatan pembelajaan. Hasil uji perbedaan dengan one-way ANOVA dapat dilihat pada Tabel IV.

TABEL IV

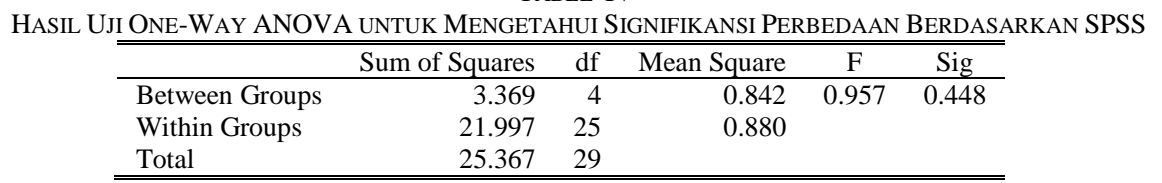

Data kuisioner yang diperoleh kemudian dikonversi menggunakan skala likert dan dihitung central tendencynya. Tabel V menunjukkan, untuk setiap pernyataan, dimulai dari P1 hingga P5 memiliki nilai central tendency $\geq$ 3.50. Apabila dilihat rata-rata secara keseluruhan nilai persetujuan untuk semua poin motivasi yang diujikan mencapai 4.49. Hal ini menunjukkan bahwa setiap pernyataan mendapatkan persetujuan siswa terkait dengan adanya peningkatan motivasi belajar ketika menggunakan aplikasi VR. Jika dilihat lebih mendalam, dapat disimpulkan bahwa rata-rata siswa yang menggunakan aplikasi BIOTALAUT VR mempunyai pengalaman belajar unik, menarik, informasi audio dan visual yang disajikan mudah dipahami, dan memberikan pengalaman belajar yang baru bagi siswa. Tabel V memperlihatkan hasil perhitungan central tendency pada setiap pernyataan motivasi.

TABEL V

Perhitungan Central Tendency Kuisioner Motivasi

\begin{tabular}{llllll}
\hline \hline Pernyataan & P1 & P2 & P3 & P4 & P5 \\
Central Tendency & 4.57 & 4.47 & 4.47 & 4.43 & 4.53 \\
\hline \hline
\end{tabular}

\section{SIMPULAN DAN SARAN}

Berdasarkan hasil analisa dan pembahasan, kesimpulan dari penelitian ini adalah sebagai berikut:

1) Evaluasi heuristik Sutcliffe yang terdiri dari 12 aturan mampu mendiagnosa masalah yang mungkin terjadi pada 
aplikasi VR semi-immersive dengan memperhatikan aspek usabilitas dan keberadaan ketika pengguna berada dalam lingkungan maya. Secara umum aplikasi BIOTALAUT VR sudah merepresentasikan kondisi alam bawah laut dengan dilengkapi objek gelombang air, cahaya, gelembung udara, dan beberapa biota laut dengan beberapa perbaikan pada fitur presence, lingkungan, kontrol, dan perangkat keras. Bagian penting yang perlu menjadi perhatian saat perbaikan disain aplikasi adalah penambahan efek benturan (Collision) pada fitur intraksi dan pengaturan ulang jalur pergerakan objek biota sehingga terlihat lebih alami.

2) Gejala cybersickness dapat terjadi pada setiap pengguna dikarenakan belum terbiasa dengan pengelihatan jarak dekat. Hasil pengujian terhadap beberapa posisi menunjukan bahwa posisi kepala ke atas atau menggelengkan kepala dengan cepat akan memicu gejala cybersickness. Selain itu, penggunaan alat kacamata tracking dan telepon pintar yang lebih baik menunjukan bahwa durasi penggunaan aplikasi menjadi lebih lama sebelum terjadinya gejala cybersickness.

3) Selain kegiatan evaluasi heuristik terhadap disain tampilan aplikasi, kegiatan implementasi VR terhadap proses pembelajaran juga dievaluasi untuk mengetahui apakah aplikasi VR khususnya aplikasi BIOTALAUT VR mampu memberikan peningkatan kemampuan kognitif dan motivasi belajar siswa. Dari hasil pengujian secara statistik, kemampuan kognitif siswa setelah menggunakan aplikasi VR ini mengalami perbedaan yang signifikan dengan nilai P-value sebesar 0.448 bila dibandingkan dengan kemampuan kognitif sebelum menggunakan aplikasi VR. Dilihat dari segi motivasi, dapat disimpulkan bahwa rata-rata siswa menyetujui setiap pernyataan kuisioner. Hal ini mengindikasikan siswa mengalami peningkatan motivasi belajar ketika menggunakan aplikasi VR.

Beberapa saran untuk pengembangan aplikasi dan penelitian selanjutnya, antara lain:

1) Selain evaluasi heuristik, pengembang aplikasi dapat juga menggunakan metode evaluasi lainnya seperti Cognitive Walkthrough untuk memandu selama proses pembuatan disain sehingga aplikasi dapat berfungsi sesuai analisa tugasnya dan mudah digunakan

2) Metode usabilitas yang ada saat ini masih perlu dikembangkan untuk melihat pengaruh teknologi VR terhadap pendidikan, sebagai contoh adalah aspek motivasi peserta didik.

3) Perlunya aplikasi dengan topik-topik lain yang bersifat abstrak misalnya pengembangan aplikasi VR untuk memperkenalkan siklus peredaran darah manusia, dan sebagainya.

4) Perlu dilakukan pengujian yang lebih komprehensif dengan melibatkan lebih banyak responden sehingga hasil yang diperoleh mewakili populasi dan hasilnya dapat digeneralisasi.

\section{UCAPAN TERIMA KASIH}

Tim peneliti mengucapkan terima kasih kepada Universitas Padjadjaran selaku pemberi Hibah Peningkatan Kapasitas Riset Dosen. Selain itu ucapan terima kasih kami sampaikan kepada sivitas akademika MTs Ma'Arif dan SMP Muhammadiyah Jatinangor atas kesediaannya menjadi responden.

\section{REFERENSI}

[1] Simsek N. and Erdogdu F., "Current Trends in Computer Use of Elementary School Students: An International Comparison," Procedia-Soc. Behav. Sci, vol. 47, no. 1998, pp. 1058-1063, 2012.

[2] Pantelidis V. S., "Reasons to Use Virtual Reality in Education and Training Courses and a Model to Determine When to Use Virtual Reality," THEMES Sci. Technol. Educ, vol. 2, pp. 59-70, 2009.

[3] Abulrub A. G., Attridge A., and Williams M. A., "Virtual Reality in Engineering Education: The Future of Creating Learning," Int. J. Emerg. Technol. Learn., vol. 6, no. 4, pp. 4-11, 2011.

[4] Häfner P., Häfner V., and Ovtcharova J., "Teaching Methodology for Virtual Reality Practical Course in Engineering Education," Procedia Comput Sci., vol. 25, pp. 251-260, 2013.

[5] Barnum C. M. Usability Testing and Research. New York: Pearson Education. 2002:151-152.

[6] Dix A., Finlay J., Abowd G. D., and Beale R. Human-Computer Interaction. Third Edition. London: Person Education. 2004.

[7] Sutcliffe A. and Gault B. Heuristic evaluation of virtual reality applications. Elsevier Interacting with computers. 2004 ; 16: 831-849.

[8] Zaharias P. and Poylymenakou A., "Developing A Usability Method Evaluation Method for E-learning Applications: Beyond Functional Usability," International Journal of Human Computer Interaction, vol. 25, no. 1, pp. 75-98, 2009

[9] Santoso H. B., "Pemodelan Personalisasi Pembelajaran berdasarkan Aspek Gaya Belajar pada Student Centered E-learning Environment," Fakultas Ilmu Komputer, Depok, 2007.

[10] Hasibuan Z. A.Desain Penelitian. Metodologi Penelitian Pada Bidang Ilmu Komputer dan Teknologi Informasi, Fakultas Ilmu Komputer Universitas Indonesia. 2007:81.

[11] LaViola Jr. J. J. A Discussion of Cybersickness in Virtual Environments. ACM SIGCHI Bull. 2000; 32(1):47-55.

[12] Bamodu O. and Ye X., "Virtual Reality and Virtual Reality System Components," in 2nd International Conference on Systems Engineering and Modeling, Paris, 2013.

[13] Chiarovano E et all, "Maintaining Balance When Looking at A Virtual Reality Three-Dimensional Display of A Field of Moving Dots or at Virtual Reality Scene.," Front. Neurol., vol. 6, no. 164, pp. 1-9, 2015.

[14] Zaveri P. P. et all, "Virtual Reality for Pediatric Sedation: A Randomized Controlled Trial Using Simulation," Cureus, vol. 8, no. 2, pp. 1-11, 2016.

[15] Rosa P. J. et all, "The Immersive Virtual Reality Experience: A Typology of Users Revealed Through Multiple Correspondence Analysis Combine with Cluster Analysis Technique," Cyberpsychology, Behavior, and Social Networking, vol. 19, no. 3, pp. 209-216, 2016.

[16] Nielsen J. Usability Engineering. Academic Press Limited. London, 1993.

[17] Usman M.U, Menjadi Guru Professional, Bandung: Rosda, 2002.

[18] Arikunto S., Pengantar Evaluasi Pendidikan, Bandung: Remaja Rosdakarya, 2001

[19] Boone H. N. and Boone D. A., "Analyzing Likert Data," Journal of Extension, vol. 50, no. 2, 2012 